\title{
RELATIONSHIP BETWEEN THE FUNCTIONAL RESERVE OF THE HEART AND THE PHYSICAL FACILITY OF ADOLESCENTS OF THE SPECIAL MEDICAL GROUP
}

\author{
Sitovskyi A.M. https://orcid.org/0000-0002-7434-7475 \\ Andriychuk O.Ya. https://orcid.org/0000-0003-4415-4696 \\ Usova O.V. https://orcid.org/0000-0002-6227-0597 \\ Yakobson O.O. https://orcid.org/0000-0002-7340-2014 \\ Ulianytska N.Ya. https://orcid.org/0000-0002-7369-8935 \\ Tsjupak T.E. https://orcid.org/0000-0002-7891-6882
}

Lesya Ukrainka Volyn National University, Lutsk, Ukraine

andriy.sitovskiy@gmail.com;

\begin{abstract}
Relevance. The most common indicators for assessing the effectiveness of health technologies are the cardiovascular performance of adolescents. At present, there is insufficient information on the quantitative substantiation of informativeness, prognostic and diagnostic significance of such indicators in the process of correction of functional and reserve capabilities of the cardiovascular system of adolescents.

Objective: to determine the levels of functional reserve of the heart according to the Rufier index and to study the physical performance of students aged 12-14 years of different medical groups.

Materials and methods. 178 seventh-eighth-graders aged 12-14 (85 boys and 93 girls) were examined. All students voluntarily participated in this experiment, and the written consent of their parents was obtained. Physical performance was studied according to the parameters of the bicycle ergometric test PWC170. The division of students into medical groups was carried out according to the indicators of the level of functional and reserve capabilities of the cardiovascular system, conducted according to the Rufier index. Statistical analysis of the results was performed using the application package Statistica-V.10.0. The normality of the distribution was checked by the Kolmogorov-Smirnov test. The studied indicators are described by the median (Me) and 25, 75 percentiles. The relationships of the studied indicators were analyzed according to Spearman's rank correlation coefficients. To determine the reliability of differences in indicators used the criterion of Kraskel Wallis.

Results. The main group included $13.5 \%$ of adolescents, the preparatory group $-35.4 \%$, the special medical group $-51.1 \%$ of students. Among student-athletes, $25.9 \%$ of boys and $45.4 \%$ of girls belong to a special medical group. In school athletes, the correlations between the Rufier index and the PWC170 test are low and statistically insignificant. Indicators of physical performance in the range of 25-75 percentiles do not differ in different medical groups. This indicates that in a special medical group there are students with medium and high levels of physical fitness.

Conclusions. The established age and gender differences in the functional reserve of the heart of schoolchildren determine the need to develop differentiated approaches to the assessment of the Rufier index. Physical performance in different medical groups varies in a fairly wide range. The division of students into medical groups according to the Rufier index does not reflect the level of physical performance of students and, accordingly, their real adaptive capabilities. Further studies are needed on the informativeness of using the Rufier test to divide students into medical groups.
\end{abstract}

Keywords: adolescents, Rufier's test, physical performance, medical groups.

Relevance. The most common indicators for assessing the effectiveness of health technologies are the cardiovascular performance of adolescents. At present, there is insufficient information on the quantitative substantiation of informativeness, prognostic and diagnostic significance of such indicators in the process of correction of functional and reserve capabilities of the cardiovascular system of adolescents.

A necessary and obligatory condition for the division of students into medical groups is to determine the functional and reserve capabilities of the cardiovascular system by the Rufier test [1].

According to a survey of pediatricians, the main need to determine the medical group for physical education is due to the entry of children into school; the beginning of the school year; registration of the child in the sports section $(70.69 \%-82.76 \%$ of cases $)$, and at the request of parents цфы only $39.66 \%$ [2].

Numerous studies indicate that according to the Rufier index, most students belong to a special medical group [3-28].

On the other hand, it is pointed out that among adolescents who are additionally engaged in sports sections, a significant part also belongs to the special and preparatory medical group according to the Rufier index $[11,23,25]$. At the same time, there is also information that the response of the cardiovascular system to exercise, according to the Rufier index, in all adolescents 13 years is below average and is almost no different from schoolchildren who do and do not play sports [24]. 
Studies that would characterize the physical performance of students of different medical groups are virtually absent. This confirms the need for further study of the functional reserve of the heart in relation to the physical performance of adolescents in different medical groups.

Objective: to determine the levels of functional reserve of the heart according to the Rufier index and to study the physical performance of students aged 12-14 years of different medical groups.

\section{MATERIAL AND METHODS}

178 seventh-eighth-graders aged 12-14 were surveyed (mean age $13.0 \pm 0.7$ years). Of these, 85 boys (mean age $13.1 \pm 0.7$ years) and 93 girls (mean age 12.9 \pm 0.7 years). The study was conducted at the beginning of the school year. All students voluntarily participated in this experiment, and the written consent of their parents was obtained. The research was performed in compliance with the basic provisions of the «Rules of ethical principles of scientific medical research with human participation», approved by the Declaration of Helsinki (1964-2013), ICH GCP (1996), EEC Directive № 609 (dated 24.11.1986), orders of the Ministry of Health of Ukraine № 690 dated 23.09.2009, № 944 dated 14.12.2009, № 616 dated 03.08.2012

Physical performance was studied according to the parameters of the bicycle ergometric test PWC170. Onetime test of stepwise increasing power for at least $9 \mathrm{~min}$ utes [30].

The division of students into medical groups was carried out according to the indicators of the level of functional and reserve capabilities of the cardiovascular system, conducted according to the Rufier index (RI) [1].

Statistical analysis was performed using the application package Statistica-v.10.0. The normality of the distribution was checked by the Kolmogorov-Smirnov test. Almost all of the studied indicators do not have a normal distribution, in this study they are described by the median $(\mathrm{Me})$ and 25, 75 percentiles. The relationships of the studied indicators were analyzed according to Spearman's rank correlation coefficients. To deter- mine the reliability of differences in indicators used the criterion of Kraskel Wallis. The difference between the indicators was considered probable at $\mathrm{p}<0.05$ [31].

\section{RESULTS AND DISCUSSION}

At the beginning of the school year, when dividing students into medical groups for physical education, the medical worker of the educational institution found that according to the Rufier index, the main medical group included $13.5 \%$ of adolescents, the preparatory group - $35.4 \%$, the special medical group. groups $-51.1 \%$ of students, ie more than half of students. Among the students of the special medical group, there was only one adolescent who had permanent health disorders $(0.6 \%$ of the total number). Among the students included in the preparatory medical group, there were three adolescents in the recovery period after acute illness $(1.8 \%$ of the total). The rest of the students were assigned to the preparatory and special medical group only according to the results of the Rufier test (Table 1).

During our further examination of students by recording an electrocardiogram (ECG), no students with clinically pronounced abnormalities on the ECG were found, which gave us grounds to determine physical performance by performing a PWC170 test [30] under ECG control. There are no other contraindications to bicycle ergometry. Three students, who were assigned to the preparatory and special medical groups according to criteria other than the functional and reserve capabilities of the cardiovascular system, were not tested.

It should be noted that there were no statistical differences between the medical groups in terms of body mass index, vital capacity (VC), vital index (VI), heart rate (HR) and blood pressure (BP) (Table 2).

When analyzing the Rufier index, depending on gender, its worst values are observed in girls. Thus, taking into account gender, the main medical group included $10.8 \%$ of girls and $16.5 \%$ of boys, the preparatory group - $25.8 \%$ of girls and $45.9 \%$ of boys, the special medical group $-63.4 \%$ of girls and $37.6 \%$ of boys (Table 1).

Table 1

Distribution of schoolchildren aged 12-14 to medical groups according to the Rufier index, absolute number (percentage)

\begin{tabular}{|c|c|c|c|c|c|c|c|c|c|}
\hline \multirow{2}{*}{ Contingent } & \multicolumn{3}{|c|}{ General sample of students } & \multicolumn{3}{|c|}{ Engaged in sports sections } & \multicolumn{3}{|c|}{ Not engaged in sports sections } \\
\hline & $\underset{(n=178)}{\text { All }}$ & $\begin{array}{c}\text { Male } \\
(n=85)\end{array}$ & $\begin{array}{l}\text { Female } \\
(n=93)\end{array}$ & $\begin{array}{c}\text { All } \\
(\mathrm{n}=\mathbf{3 8})\end{array}$ & $\begin{array}{r}\text { Male } \\
(n=27)\end{array}$ & $\begin{array}{l}\text { Female } \\
(\mathrm{n}=11)\end{array}$ & $\begin{array}{c}\text { All } \\
(n=140)\end{array}$ & $\begin{array}{c}\text { Male } \\
(\mathrm{n}=58)\end{array}$ & $\begin{array}{l}\text { Female } \\
(n=82)\end{array}$ \\
\hline Main group & $\begin{array}{c}24 \\
(13,5)\end{array}$ & $\begin{array}{c}14 \\
(16,5)\end{array}$ & $\begin{array}{c}10 \\
(10,8)\end{array}$ & $\begin{array}{c}12 \\
(31,6)\end{array}$ & $\begin{array}{c}9 \\
(33,3)\end{array}$ & $\begin{array}{c}3 \\
(27,3)\end{array}$ & $\begin{array}{c}12 \\
(8,6)\end{array}$ & $\begin{array}{c}5 \\
(8,6)\end{array}$ & $\begin{array}{c}7 \\
(8,5)\end{array}$ \\
\hline $\begin{array}{l}\text { Preparatory } \\
\text { group }\end{array}$ & $\begin{array}{c}63 \\
(35,4)\end{array}$ & $\begin{array}{c}39 \\
(45,9)\end{array}$ & $\begin{array}{c}24 \\
(25,8)\end{array}$ & $\begin{array}{c}14 \\
(36,8)\end{array}$ & $\begin{array}{c}11 \\
(40,7)\end{array}$ & $\begin{array}{c}3 \\
(27,3)\end{array}$ & $\begin{array}{c}49 \\
(35,0)\end{array}$ & $\begin{array}{c}28 \\
(48,3)\end{array}$ & $\begin{array}{c}21 \\
(25,6)\end{array}$ \\
\hline $\begin{array}{l}\text { Special } \\
\text { group }\end{array}$ & $\begin{array}{c}91 \\
(51,1)\end{array}$ & $\begin{array}{c}32 \\
(37,6)\end{array}$ & $\begin{array}{c}59 \\
(63,4)\end{array}$ & $\begin{array}{c}12 \\
(31,6)\end{array}$ & $\begin{array}{c}7 \\
(25,9)\end{array}$ & $\begin{array}{c}5 \\
(45,4)\end{array}$ & $\begin{array}{c}79 \\
(56,4)\end{array}$ & $\begin{array}{c}25 \\
(43,1)\end{array}$ & $\begin{array}{c}54 \\
(65,9)\end{array}$ \\
\hline
\end{tabular}


Comparative characteristics of schoolchildren 12-14 years old, not involved in sports, different medical groups, Me (Q1-Q3)

\begin{tabular}{|c|c|c|c|}
\hline Indicator & Main group $(n=12)$ & Preparatory group $(n=49)$ & Special group $(n=79)$ \\
\hline Age, year & $12,8 \pm 0,5$ & $12,9 \pm 0,7$ & $13,0 \pm 0,7$ \\
\hline Body mass index, $\mathrm{kg} / \mathrm{m}^{2}$ & $\begin{array}{c}17,2 \\
(16,3-20,0)\end{array}$ & $\begin{array}{c}18,5 \\
(16,2-19,8)\end{array}$ & $\begin{array}{c}18,9 \\
(17,4-20,9)\end{array}$ \\
\hline LVC, 1 & $\begin{array}{c}2,38 \\
(2,16-2,44)\end{array}$ & $\begin{array}{c}2,59 \\
(2,22-2,99)\end{array}$ & $\begin{array}{c}2,47 \\
(2,14-2,94)\end{array}$ \\
\hline $\mathrm{VI}, \mathrm{ml} / \mathrm{kg}$ & $\begin{array}{c}57,7 \\
(53,7-60,5)\end{array}$ & $\begin{array}{c}58,8 \\
(51,1-63,7)\end{array}$ & $\begin{array}{c}52,3 \\
(45,2-61,1)\end{array}$ \\
\hline $\mathrm{HR}, \mathrm{b} / \mathrm{mn}$ & $\begin{array}{c}83,1 \\
(77,7-88,7)\end{array}$ & $\begin{array}{c}85,0 \\
(77,6-92,9)\end{array}$ & $\begin{array}{c}88,7 \\
(82,6-97,6)\end{array}$ \\
\hline $\begin{array}{l}\text { BP systolic, } \\
\mathrm{mmHg}\end{array}$ & $\begin{array}{c}114,0 \\
(103,0-121,0)\end{array}$ & $\begin{array}{c}113,0 \\
(101,0-122,0)\end{array}$ & $\begin{array}{c}116,0 \\
(110,0-126,0)\end{array}$ \\
\hline $\begin{array}{l}\text { BP diastolic, } \\
\mathrm{mmHg}\end{array}$ & $\begin{array}{c}71,0 \\
(64,0-81,5)\end{array}$ & $\begin{array}{c}70,0 \\
(64,0-76,0)\end{array}$ & $\begin{array}{c}72,0 \\
(65,0-79,0)\end{array}$ \\
\hline
\end{tabular}

In connection with the reports that according to the results of Rufier's test, the special medical group also unreasonably includes students who regularly participate in sports sections [11, 23, 25], we analyzed the employment of the studied students in sports sections. It was found that 38 out of 178 schoolchildren regularly participate in sports sections lasting at least one year and often at least three times a week. Analysis of the Rufier index of students involved in sports sections found that $31.6 \%$ of students belong to a special medical group, $36.8 \%$ of students - preparatory and only $31.6 \%$ of students - to the main medical group (Table. 1). This indicates the inadequacy of the assessment of the functional reserve of the heart of adolescents after the Rufier test.

The analysis of the levels of functional and reserve capabilities of the cardiovascular system in student-athletes revealed that $25.9 \%$ of boys and $45.4 \%$ of girls belong to a special medical group according to the Rufier index (Table 1).

The division of students into medical groups, except for boys and girls who play sports, shows the same ratio of students in groups as in the combined sample: the main medical group included $8.6 \%$ of adolescents, the preparatory group $-35.0 \%$, to a special medical group $56.4 \%$ of students. Similar gender differences were also found: more girls than boys were included in the special medical group (65.9\% and $43.1 \%$, respectively). Only $8.6 \%$ of schoolchildren aged $12-14$ who do not participate in sports sections belong to the main medical group (Table 1). Although, only $31.6 \%$ of schoolchildren-athletes belong to the main medical group (Table 1).

According to the results of the PWC170 test, the worst indicators of physical performance were found in schoolchildren of the special medical group against the background of the worst functional reserve of the heart according to the Rufier test. It should be noted that the indicators of physical performance in the range of 25-75 percentiles do not differ in different medical groups. This indicates that in a special medical group there are students with medium and high levels of efficiency (Table 3).

According to the correlation analysis, it was found that in the general sample, adolescents with a higher level

Table 3

Physical capacity and adaptive abilities of schoolchildren 12-14 years old, not engaged in sports, different medical groups, Me (Q1-Q3)

\begin{tabular}{|l|c|c|c|}
\hline \multicolumn{1}{|c|}{ Indicator } & Main group (n=12) & Preparatory group (n=46) & Special group (n=78) \\
\hline \multirow{2}{*}{ PWC $_{170}, \mathrm{~kg} \times \mathrm{m} / \mathrm{mn}$} & 526,9 & 526,7 & 456,3 \\
& $(468,0-536,7)$ & $(446,4-642,0)$ & $(385,6-550,0)$ \\
\hline \multirow{2}{*}{ PWC $_{170}, \mathrm{~kg} \times \mathrm{m} \times \mathrm{mn} / \mathrm{kg}$} & 12,5 & 12,0 & $9,4 \square$ \\
\hline \multirow{2}{*}{ Rufier Index, c.u. } & $(12,3-13,4)$ & $(10,1-14,4)$ & $(8,4-11,0)$ \\
& $5,8^{*}$ & $8,4 *$ & 12,0 \\
& $(4,8-6,2)$ & $(7,6-9,2)$ & $(10,4-13,2)$ \\
\hline
\end{tabular}

Notes: $\#-p<0.05$ compared to the main group; $\square-p<0,05$ in comparison with the preparatory group; $*-p<0,05$ compared to a special medical group 
of functional reserve of the heart, according to the Rufier index, are characterized by higher absolute and relative indicators of physical performance $(\mathrm{p}<0.05)$.

In the analysis of correlations separately for groups of schoolchildren who are engaged and not engaged in sports, it is established that in schoolchildren-athletes these interrelations are low and statistically insignificant, and in the group of non-athletes the correspondence of the highest level of functional reserve of heart remains higher. $(\mathrm{p}<0.05)$ (Table 4).

This confirms the well-known natural relationships between physical performance and cardiovascular function. However, it does not reflect clear differences in levels of physical performance between different medical groups. Because in each medical group the PWC170 test values fluctuate in a fairly wide range according to the percentile analysis (Table 3). And the presence of a correlation between the PWC170 test and the Rufier test can be explained by the presence of a common factor in their calculation - heart rate.

We analyzed 14 studies by different authors over the past 10 years, with a sample of more than 6,800 students aged 7-17, which divided students into medical groups based on the results of the Ruffier test and the methodology recommended by order of the Ministry of Health of Ukraine and the Ministry of Education and Science of Ukraine dated 20.07.2009 № 518/674 [1]. Summary statistics of these studies show that $66.8 \%$ of students belong to the special medical group, $23.4 \%$ of students to the preparatory group and only $9.8 \%$ of schoolchildren to the main group (Table 5).

The inadmissibility of the Rufier test by paramedics is pointed out [25]. Because there are significant differences in the test results of the same students (autumn and spring) by the average medical staff of the clinic $(0 \%$ of students in the special medical group) and scientists of the medical university (43\% of students in the special medical group). Although there are data [17] obtained from the registration form № 026/u in 5318 schoolchildren, $44.7 \%$ belong to the special medical group, $35.4 \%$ to the preparatory group, and $19.9 \%$ to the main medical group (Table 5).

It is noted that the performance of this test by students at the beginning of the school year, designed for highclass athletes, causes a natural inadequate response of the cardiovascular system [23].

According to the results of the Rufier test in schoolchildren aged 6-17, it is concluded that the test performs submaximal power of anaerobic-aerobic nature and suggests using it as an indirect criterion of physical performance [15]. Our study also found a reliable association between the Rufier test and the PWC170 test in a pooled sample and a group of non-sports students. But in the group of schoolchildren-athletes such correlation is insignificant (Table 4). At the same time, it is noted that the excellent results of the Rufier test do not always indicate high efficiency, which is also confirmed by us [9].

It is noted that the Rufier test should be used to assess the functional state of athletes and the author's method (30 squats in $30 \mathrm{~s}$ ), because it gives a higher percentage of compliance with the assessment of physical fitness of students and their ability to perform loads [23, 25].

According to our data, more girls than boys are included in the special medical group (65.9\% and $43.1 \%$, respectively). The results of our research are confirmed by a number of authors. In particular, there are data that more girls than boys of the seventh grade $(69.5 \%$ and $48.7 \%$, respectively) and sixth grade $(59.5 \%$ and $30.4 \%$, respectively) are included in the special medical group [8]. In the eighth grade, the ratio of girls to boys in the special medical group is almost the same $(65.0 \%$ and $65.4 \%$, respectively). According to other authors, the special medical group also includes slightly more girls than boys aged $11-12$ (97.1\% and $89.8 \%$, respectively) (Table 5) [21]. At the same time, according to other authors, the special medical group includes more boys than girls aged 13-14 (100.0\% and 76.7\%, respectively) (Table 5) [19].

The number of students belonging to a special medical group ranges from $30.4 \%$ of students, according to some data [7] - for boys in sixth grade, up to $100 \%$ of students, according to other data [19], - for boys 13-14 years. The number of students in the main group also varies in a fairly wide range: from $0 \%$ - for boys and girls 11-12 years [21], for schoolchildren 14-16 years [11], for boys 13-14 years [19], to 32, 7\% of students - for boys in the seventh grade [7] (Table 5).

According to our data, in the distribution of schoolchildren 12-14 years old who do not play sports, $8.6 \%$ of adolescents were included in the main group, $35.0 \%$ in the preparatory group, and $56.4 \%$ in the special medical group. Similar summary results for schoolchildren 11-15 were obtained by a number of other authors, according to which the main group included $11.7 \%$ of adolescents, the preparatory group $-22.0 \%$, the special

Table 4

Spearman's rank correlation coefficients

\begin{tabular}{|l|c|c|c|}
\hline \multirow{2}{*}{\multicolumn{1}{|c|}{ Indicator }} & \multicolumn{3}{|c|}{ Rufier Index, c.u. } \\
\cline { 2 - 4 } & all studens & not engaged sports & engaged sports \\
\hline $\mathrm{PWC}_{170}, \mathrm{~kg} \times \mathrm{m} / \mathrm{mn}$ & $-0,217 *$ & $-0,171$ & $-0,081$ \\
\hline $\mathrm{PWC}_{170}, \mathrm{~kg} \times \mathrm{m} \times \mathrm{mn} / \mathrm{kg}$ & $-0,340 *$ & $-0,329 *$ & $-0,194$ \\
\hline
\end{tabular}

Note: ${ }^{*}-p<0,05$. 
Table 5

Summary statistics of the assessment of the functional reserve of the heart and the distribution of schoolchildren aged 7-17 to medical groups, according to the results of the Rufier test, $\%$

\begin{tabular}{|c|c|c|c|c|c|}
\hline $\begin{array}{l}\text { Levels of functional reserve of the heart, according to the } \\
\text { Rufier index, c.u. }\end{array}$ & $\begin{array}{l}\text { Low } \\
\geq 15 \text { c.u. }\end{array}$ & $\begin{array}{l}\text { Passable } \\
10-14 \text { c.u. }\end{array}$ & $\begin{array}{l}\text { Medium } \\
7-9 \text { c.u. }\end{array}$ & $\begin{array}{l}\text { Good } \\
4-6 \text { c.u. }\end{array}$ & $\begin{array}{l}\text { High } \\
\leq 3 \text { c.u. }\end{array}$ \\
\hline Medical groups, according to the Rufier index & \multicolumn{2}{|c|}{ Special } & Preparatory & \multicolumn{2}{|c|}{ Main } \\
\hline $\begin{array}{l}\text { Vakulenko L.O. }(2015) \text {, } \\
\text { students in grades } 4-11, \mathrm{n}=140\end{array}$ & 25 & 47 & 18 & 9 & 1 \\
\hline $\begin{array}{l}\text { Vasyukova M.M. (2015), } \\
\text { average school age, } \mathrm{n}=75\end{array}$ & 28 & 40 & 21,4 & 9,3 & 1,3 \\
\hline $\begin{array}{l}\text { Gerasimenko S.Yu. (2019), } \\
\text { 6th grade girls, } n=64\end{array}$ & 16,75 & 42,71 & 29,35 & 11,19 & - \\
\hline $\begin{array}{l}\text { Gerasimenko S.Yu. (2019), } \\
\text { 7th grade girls, } n=64\end{array}$ & 15,95 & 53,52 & 20,32 & 10,21 & - \\
\hline $\begin{array}{l}\text { Gerasimenko S.Yu. (2019), } \\
\text { 8th grade girls, } n=62\end{array}$ & 8,71 & 56,25 & 29,61 & 5,43 & - \\
\hline $\begin{array}{l}\text { Gerasimenko } S . Y u \text {. (2019), } \\
\text { 6th grade boys, } n=64\end{array}$ & 9,41 & 20,94 & 59,91 & 9,74 & - \\
\hline $\begin{array}{l}\text { Gerasimenko S.Yu. (2019), } \\
\text { 7th grade boys, } n=64\end{array}$ & 9,81 & 38,93 & 18,61 & 32,65 & - \\
\hline $\begin{array}{l}\text { Gerasimenko S.Yu. (2019), } \\
\text { 8th grade boys, } n=62\end{array}$ & 9,34 & 56,01 & 15,74 & 18,91 & - \\
\hline $\begin{array}{l}\text { Zakrevsky AN (2016), schoolchildren aged } 14-16 \text { who are } \\
\text { not additionally engaged in sports sections, } n=40\end{array}$ & 62,5 & 30 & 7,5 & - & - \\
\hline $\begin{array}{l}\text { Kapranov SV (2016), } \\
\text { high school students, } \mathrm{n}=5318\end{array}$ & \multicolumn{2}{|c|}{44,72} & 35,41 & \multicolumn{2}{|c|}{19,87} \\
\hline $\begin{array}{l}\text { Krutsevich T.Yu. }(2016) \\
\text { girls } 13-14 \text { years, } \mathrm{n}=30\end{array}$ & 53,33 & 23,33 & 20 & 3,3 & - \\
\hline $\begin{array}{l}\text { Krutsevich T.Yu. }(2016) \\
\text { boys } 13-14 \text { years, } n=32\end{array}$ & 75 & 25 & - & 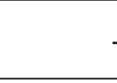 & \\
\hline $\begin{array}{l}\text { Lewandowska L. }(2015) \text {, } \\
\text { girls } 11-12 \text { years, } n=70\end{array}$ & 31,43 & 65,71 & 2,86 & - & - \\
\hline $\begin{array}{l}\text { Lewandowska L. }(2015) \text {, } \\
\text { boys } 11-12 \text { years, } \mathrm{n}=78\end{array}$ & 28,21 & 61,54 & 10,26 & - & - \\
\hline $\begin{array}{l}\text { Melnichuk L.V. }(2016) \text {, } \\
\text { schoolchildren aged 7-17, } \mathrm{n}=151\end{array}$ & 24,66 & 47,56 & 21,96 & 5,13 & 0,6 \\
\hline $\begin{array}{l}\text { Kaminska T.M. (2016), } \\
\text { primary school age, } \mathrm{n}=201\end{array}$ & 40,8 & 45,8 & 11,9 & 1,0 & 0,5 \\
\hline $\begin{array}{l}\text { Kaminska TM (2016), } \\
\text { average school age, } \mathrm{n}=221\end{array}$ & 19,9 & 40,7 & 29,4 & 10,0 & - \\
\hline $\begin{array}{l}\text { Kaminska TM (2016), } \\
\text { senior school age, } \mathrm{n}=126\end{array}$ & 17,5 & 28,3 & 42,1 & 10,3 & 1,6 \\
\hline $\begin{array}{l}\text { Novikov EV (2010), } \\
\text { schoolchildren aged 14-15, n=21 }\end{array}$ & \multicolumn{2}{|c|}{43} & 43 & \multicolumn{2}{|c|}{14} \\
\hline $\begin{array}{l}\text { Tyazhka A. V. (2011), students of 2-6 } \\
\text { grades of secondary school, } n=81\end{array}$ & 7,4 & 40,7 & 32,1 & 17,3 & 2,5 \\
\hline $\begin{array}{l}\text { Tyazhka A. V. (2015), } \\
\text { students of 5-6 grades of gymnasium, } n=75\end{array}$ & 28 & 40 & 21,4 & 9,3 & 1,3 \\
\hline Summary statistics & \multicolumn{2}{|c|}{66,8} & 23,4 & \multicolumn{2}{|c|}{9,8} \\
\hline
\end{tabular}

medical group $-66.3 \%$ of schoolchildren $[5,8,16,19$, 25] (Table 5).

In our research, among students-athletes, the main group included only $30.4 \%$ of adolescents, the preparatory group $-34.0 \%$, the special medical group - $35.7 \%$ of students. Similar results were obtained by other authors [11] - according to their data, the main group also includes only $30.0 \%$ of students who play sports, but the preparatory group includes $60.0 \%$ of students, and the special medical group $10.0 \%$ students (Table 5). The author also notes that there is a significant difference between students-athletes and those who are not additionally engaged in sports sections, in terms of functional reserve of the heart.

It is noted that the response of the cardiovascular system to exercise, according to the Rufier index, in all 
adolescents 13 years is below average and is almost no different from students who are engaged in and are not engaged in additional hiking [24].

A number of authors note the low informativeness of the Rufier test, compared with the Martin-Kushelevsky test, and consider it insufficient to determine the functional status of adolescents [10,23].

When assessing the objectivity of the method of determining and dividing children into medical groups for physical education, it is noted that the most sensitive group to the shortcomings of the educational process are middle school children, especially girls, and more than $30 \%$ of secondary school students are unable to perform Rufier's test. specified in the official protocol of medical and pedagogical control over the physical education of schoolchildren [2].

There is also an opinion that generally calls into question the correctness of the use of the Rufier test for school-age children [12].

When evaluating the Rufier test in students in grades 4-11 according to the methods proposed in the Order, a number of caveats are indicated. First of all, it is the lack of gradation by age and gender [4].

Having obtained a significant positive correlation between the results of the sample and the age of the subjects, some authors recommend the use of age-adjusted corrections when determining the Rufier index [9, 12, 28]. This is also confirmed by our review of the results of studies by different authors, which found (sometimes significant) differences in the distribution of students into medical groups based on age and gender (Table 5). Which, obviously, indicates the presence of age and sex characteristics of the functional reserve of the heart in different periods of ontogenesis.

It should be noted that there is virtually no data on the functional reserve of the heart, according to the Rufier index, at specific ages and taking into account the sex of students. In this aspect, attention is drawn to studies and recommendations for differentiated assessment of the Rufier index according to the age of students [12-14, 29]. And the gender differences obtained by us and other authors $[8,19,21]$ of the Rufier index actualize the issue of differentiated assessment of the Rufier index according to the sex of schoolchildren.

No less important aspect is the consideration of sports qualifications of schoolchildren. Only a few authors indicate whether schoolchildren-athletes were excluded from the analysis of the Rufier index, and give a comparative description of the functional reserve of the heart of these categories of schoolchildren [11].

In addition, the complexity and ambiguity of the results of various studies in adolescence, apparently, is determined by the individual rate of biological development of students during puberty [32-34] and the school year (increasing student fatigue during the school year) $[19,20]$. This should also be taken into account when planning further studies on the informativeness of the assessment of the functional reserve of the heart based on the results of the Rufier test.

Therefore, we believe that further study is needed on the informativeness of the use of the Rufier test to divide students into medical groups. In the future, the assessment of the functional reserve of the heart will be carried out according to the recommendations of IP Zanevsky on taking into account age in assessing the Rufier index, and study on this basis physical performance and autonomic adaptive capacity of students 12-14 years of different medical groups.

\section{CONCLUSIONS}

The established age and gender differences in the functional reserve of the heart of schoolchildren determine the need to develop differentiated approaches to the assessment of the Rufier index.

Physical performance in different medical groups varies in a fairly wide range. The division of students into medical groups according to the Rufier index does not reflect the level of physical performance of students and, accordingly, their real adaptive capabilities.

Connection of work with scientific programs, plans, topics. This study was performed in the framework of research «Development of models of rehabilitation effects in physical therapy and occupational therapy and evaluation of their effectiveness from the standpoint of evidence-based medicine» (№ 0119U001190).

\section{REFERENCES}

1. [On ensuring medical and pedagogical control over the physical education of students in secondary schools]: Order of the Ministry of Health of Ukraine and the Ministry of Education and Science of Ukraine N 518/674 of 20.07.2009 [in Ukrainian].

View at: Access mode:https://zakon.rada.gov.ua/laws/ show/z0773-09

2. Kozyarin IP, Ivakhno OP. [Adequacy of methods for determining the level of physical health of children for physical education]. Collection of scientific works of Shupik NMAPE. Kyiv, 2016; 26: 40-4. [in Ukrainian]. View at: URL: http://lib.inmeds.com.ua:8080/jspui/ bitstream/lib/1050/1/zbornikNMAPO26-41-45.pdf

3. Borisova Yu.Yu. [Assessment of the level of physical health of schoolchildren aged 7-17]. Scientific journal of the Dragomanov National Pedagogical University. Series 15: Scientific and pedagogical problems of physical culture (physical culture and sports). 2016; 10(80): 30-3. [in Ukrainian].

View at: URL: http://enpuir.npu.edu.ua/ handle/123456789/20028

4. Vakulenko LO, Vakulenko DV, Barladin OR, Brave SZ, Bobelyak NP [Informative value of Rufier's functional test in the formation of harmoniously developed youth]. Materials of the regional scientific-methodical seminar 
"Olympic movement in Western Ukraine - past and present”. Ternopil: TYPE, 2015: 19-21. [in Ukrainian].

5. Vasyukova M.M., Kazakova L.N., Antoshkina A.N., Kazmirchuk O.N., Korvach Kh.O. [Features of health of pupils of secondary school age in the gymnasium of Kyiv]. The world of science and innovation. 2015; 13 (2): 36-43. [in Russian].

View at: URL: https://www.elibrary.ru/item. asp?id=25118143

6. Gerasimenko S.Yu., Zhigulyova EO. [Assessment of the level of physical fitness of 8 th grade students]. Bulletin of Kamyanets-Podilsky Ogienko National University. Physical education, sports and human health. 2019; 12. 7-10. [in Ukrainian].

View at: Publisher Site: http://visnyk-sport.kpnu.edu. ua/article/view/178559

7. Gerasimenko SY, Lukyanchenko MI. [Assessment of the level of physical fitness of 7th grade students]. Scientific journal of the Drahomanov National Pedagogical University. Series 15: Scientific and pedagogical problems of physical culture (physical culture and sports). 2019; 5K(113): 64-8. [in Ukrainian].

View at: URL: http://enpuir.npu.edu.ua/ handle/123456789/26870

8. Gerasimenko SY, Lukyanchenko EV. [Assessment of the level of physical fitness of 6th grade students]. Actual problems of medical and biological support of physical culture, sports and physical rehabilitation. V International Scientific and Practical Internet Conference April 25-26, 2019. Kharkiv: KhDAFK, 2019: 19-24. [in Ukrainian]. View at: URL: http://reposit.uni-sport.edu.ua/bitstream/handle/787878787/1669/\%D0\%97\%D0\%B1 $\% \mathrm{D} 1 \% 96 \% \mathrm{D} 1 \% 80 \% \mathrm{D} 0 \% \mathrm{BD} \% \mathrm{D} 0 \% \mathrm{~B} 8 \% \mathrm{D} 0 \% \mathrm{BA} \% 20$ $\% \mathrm{D} 0 \% \mathrm{~A} 1 \% \mathrm{D} 0 \% 9 \mathrm{C} \% \mathrm{D} 0 \% 91 \% \mathrm{D} 0 \% 90 \% 202019 \% 20$ $\%$ D0\%9F\%D1\%83\%D1\%82\%D1\%80\%D0\%BE. pdf? sequence $=1 \&$ is Allowed $=y$

9. Guseva A.A. [Methodological approaches to the assessment of Ruffier's test in young athletes]. Physical education in prevention, treatment and rehabilitation. 2006; 1 (16): 44-6. [in Russian].

10. Evdokimov EI, Golets VO. [Informativeness of multifactorial rapid diagnostics and Rufier's test in determining the functional state of schoolchildren]. Bulletin of Zaporizhia National University. Physical education and sports. 2010; 1 (3): 88-91. [in Ukrainian].

View at: URL: https://web.znu.edu.ua/herald/issues/2010/Fzv-1-2010/088-89.pdf

11. Zakrevsky A.N., Karapetyan O.Yu., Timchenko A.N., Smal V.A. [The role of remote ECG-counseling and pulse oximetry in a comprehensive assessment of the health status of schoolchildren]. Problems of modern education. Collection of scientific and methodical works. Kharkiv: Karazin KhNU, 2016; Issue 7: 68-75. [in Russian].

View at: URL: http://dspace.univer.kharkov.ua/bitstream/123456789/12552/2/Problemy_7_2016.pdf

12. Zanevsky IP. [Rufier's test as a method of diagnosing the functional state of the cardiovascular system of school-age children]. Sports science of Ukraine. 2011; 3: 71-92. [in Ukrainian].

View at: URL: http://repository.ldufk.edu.ua/bitstream/ $34606048 / 17192 / 1 / \% \mathrm{D} 0 \% 97 \% \mathrm{D} 0 \% \mathrm{~B} 0 \% \mathrm{D} 0 \% \mathrm{~B} \% \mathrm{D} 0 \%$ B5\%D0\%B2\%D1\%81\%D1\%8C\%D0\%BA\%D0\%B8\% D0\%B9\%20\%D0\%86\%D0\%B3\%D0\%BE\%D1\%80. pdf

13. Zanevsky I., Sanotska N. [Rufier's test and the rate of resting heart rate]. Sports science of Ukraine. 2014; (59): 43-50. [in Ukrainian].

View at: Publisher Site: http://sportscience.ldufk.edu. ua/index.php/snu/article/view/212

14. Zanevsky IP, Zanevskaya LG. [Ruffier test model taking into account an age of the patient]. Theory and methods of physical education. 2013; 2: 17-27. [in Ukrainian]. DOI: $10.17309 /$ tmfv.2013.2.1013

View at: Publisher Site: http://dx.doi.org/10.17309/ tmfv.2013.2.1013

ResearchGate: https://www.researchgate.net/publication/276346514_Model_probi_Ruf'e_z_urahuvannam_viku_pacienta

15. Kalinichenko I.O. [The use of the Rufier test to assess the functional capabilities of the body of children 6-17 years]. Science and education. 2012; 4 (CVV): 82-86. [in Ukrainian].

View at: URL: https://scholar.google.com.ua/citations?user=-qwMKyoAAAAJ\&hl=ru\#d=gs_md_cita-d\&u=\%2Fcitations $\% 3$ Fview_op $\% 3$ Dview_citation $\% 26 \mathrm{hl} \% 3 \mathrm{Dru} \% 26 \mathrm{user} \% 3 \mathrm{D}$-qwMKyoAAAAJ\%26citation_for_view\%3D-qwMKyoAAAAJ\%3AP5F9QuxV20EC\%26tzom\%3D-120

16. Kaminska TM. [Optimization of the system of preventive measures and rehabilitation of health disorders of school-age children]. The dissertation of the doctor of medical sciences. Kyiv. 2016. [in Ukrainian].

View at: URL: http://ipag-kiev.org.ua/wp-content/uploads/2016/09/Dis-Kamin.pdf

17. Kapranov S.V., Kapranova Yu.S., Tarabtsev D.V. [Development of an automated system for monitoring indicators of the functional state of the cardiovascular system of children and adolescents]. In: Sanitary and Epidemiological Service of the Republic of Belarus: history, topical problems at the present stage and development prospects. Proceedings of the Intern. scientific-practical conf. Health and the Environment, dedicated to the 90th anniversary of the sanitary-epidemiological service of the Republic of Belarus, Minsk, October 28. 2016: in 2 volumes / editorial board: N.P. Zhukova [and others]. Minsk: BSMU, 2016.Vol. 1: 284-288. [in Russian].

View at: URL: http://rep.bsmu.by/handle/BSMU/12438 18. Klapchuk V. [Physical condition of man: the search for diagnostic criteria]. Actual problems of physical education of students in the conditions of credit-modular system of training: materials of the All-Ukrainian scientific and practical conference on April 10-14, 2014 Dnipropetrovsk, 2014: 211-216. [in Ukrainian]. 
View at: URL: http://www.dnu.dp.ua/docs/zbirniki/ sport/program_56d5c9b4cee79.pdf

19. Krutsevich T., Napadiy A., Imas T., Trachuk S. [Dynamics of adaptation-reserve capabilities of schoolchildren aged 13-14 years during the school year]. Sports Bulletin of the Dnieper. 2016; 1. 182-186. [in Ukrainian]. View at: URL: http://reposit.uni-sport.edu.ua/ handle/787878787/1009

20. Kurtova G.Yu., Lyapin VP, Babarika YR, Grishko LG. [Monitoring the health of schoolchildren aged 14-15 in the educational process]. Bulletin of Chernihiv National Pedagogical University. Series: Pedagogical sciences. Physical education and sports. 2015; 129 (3): 191-194. [in Ukrainian].

View at: URL: http://nbuv.gov.ua/UJRN/ VchdpuPN_2015_129(3)_46

21. Lewandowska L. [The influence of individualization of the process of physical education on the efficiency of school-age children]. Physical education, sports and health culture in modern society. 2015; 4 (32). 94-98. [in Ukrainian].

View at: URL: http://nbuv.gov.ua/UJRN/Fvs_2015_4_25

22. Melnichuk LV, Bandura SM. [Predicting the risks of reduced tolerance to physical activity during preventive examinations of schoolchildren]. Medical forum. 2016; (07): 119-121. [in Ukrainian].

View at: URL: http://nbuv.gov.ua/UJRN/ bumv_2017_21_1_19.

23. Mikhalyuk E.L. The use of the Rufier test to determine the medical group for schoolchildren: unjustified hopes. Вісник Bulletin of Chernihiv National Pedagogical University. Series: Pedagogical sciences. Physical education and sports. 2013; 107 (2). 63-66. [in Russian].

24. Mulik KV, Grinyova TI. [The impact of hiking on the health of 13-year-olds]. Pedagogy, psychology and medical and biological problems of physical education and sports. 2015; 8: 40-45. [in Ukrainian]. DOI: 10.15561/18189172.2015.0806

View at: Publisher Site: https://sportpedagogy.org.ua/ index.php/PPS/article/view/134

ResearchGate: https://www.researchgate.net/publication/282523290_Influence_of_hiking_trainings_ on_13_years_old_adolescents'_health

URL: https://www.sportpedagogy.org.ua/html/journal/2015-08/html-en/15mkvoah.html

25. Novikov E.V., Tkalich Ya.I. Rufier's test in schoolchildren: first results. Current issues of pharmaceutical and medical science and practice. 2010; 23 (4): 94-95. [in Russian].

26. Tyazhka OV, Kazakova LM, Stroy OA, Vasyukova MM, Antoshkina AM, Vakulovskaya TO, Trofimenko TO Modern features of the state of health of young and middle-aged children in Kyiv. Child health. 2011; (4): 31. [in Ukrainian].

View at: Publisher Site: http://www.mif-ua.com/ archive/article/23035

27. Tyazhka OV, Kazakova LM, Vasyukova MM, Antoshkina AM. [The state of health of middle school students in one of the gymnasiums in Kyiv]. Neonatology, surgery and perinatal medicine. 2015; 1 (5): 19-23. [in Ukrainian].

View at: URL: http://nbuv.gov.ua/UJRN/ Nkhpm_2015_5_1_5

28. Shakhnazaryan K.E., Vladova V.S. [The significance of age-related heart rate indicators for taking into account the results of the Rufier test in students]. Sports medicine, physical therapy and valeology. 2012; 113-115. [in Russian]

29. Zanevskyy I., Janiszewska R., Zanevska L. Validity of Ruffier test in evaluation of resistance to the physical effort. Journal of Testing and Evaluation. 2017; 45(6): 2193-2199. DOI: 10.1520/JTE20160380

View at: Publisher Site: https://www.astm.org/DIGITAL_LIBRARY/JOURNALS/TESTEVAL/PAGES/ JTE20160380.htm

ResearchGate: https://www.researchgate.net/publication/314084013_Validity_of_Ruffier_Test_in_Evaluation_of_Resistance to the_Physical_Effort

30. Council of Europe. Committee of Experts on Sports Research. EUROFIT: Handbook for the EUROFIT tests of Physical Fitness. Rome, Strasbourg. 1987

31. Glantz S. Biomedical statistics. Moscow: Practice. 1999. 459 p. [in Russian].

View at: URL: http://www.endosurgery.od.ua/uploaded/ site321_Medico-biologicheskaya_statistica.PDF

32. Sitovsky AM. [Annual dynamics of physical working capacity of 7th grade girls in the conditions of three physical education lessons depending on the pace of their biological development]. Modern health and rehabilitation technologies. 2005; 1: 146-150. [in Ukrainian].

View at: URL: https://uu.edu.ua/upload/Nauka/Electronni_naukovi_vidannya/Suchasni_ozdorovcho_reabilitaciyni_tehnologii/SORT_1_2005.pdf

33. Sitovsky A. [Physical performance of adolescents in terms of differentiated physical education, taking into account the rate of their biological maturation]. Physical education, sports and health culture in modern society. 2009; 1 (5): 61-65. [in Ukrainian].

View at: URL: http://nbuv.gov.ua/UJRN/Fvs_2009_1_18

34. Sitovsky A.M., Chizhik V.V. [Dynamics of indicators of physical development of adolescents in the process of their biological maturation]. Modern health and rehabilitation technologies. 2011; 6: 82-90. [in Ukrainian]. View at: URL: https://uu.edu.ua/upload/Nauka/Electronni_naukovi_vidannya/Suchasni_ozdorovcho_reabilitaciyni_tehnologii/SORT_6_2011.pdf

Article history Received: 10.01.2021 Revision requested: 18.02 .2021 Revision received: 15.03 .2021 Accepted: 29.03 .2021 


\title{
ВЗАСМОЗВ'ЯЗОК ФУНКЦІОНАЛЬНОГО РЕЗЕРВУ СЕРЦЯ ТА ФІЗИЧНОЇ ПРАЦЕЗДАТНОСТІ ПІДЛТКІВ СПЕЦІАЛЬНОЇ МЕДИЧНОЇ ГРУПИ
}

\author{
Сітовський А.М., Андрійчук О.Я., Усова О.В., Якобсон О.О., Ульяницька Н.Я., Цюпак Т.С. \\ Волинський національний університет імені Лесі Українки, Луиььк, Україна \\ andriy.sitovskiy@gmail.com;
}

\begin{abstract}
Актуальність. Найбільш поширеними індикаторами оцінки ефективності здоров'язберігаючих технологій $є$ показники діяльності серцево-судинної системи підлітків. На сьогодні відомостей кількісного обгрунтування інформативності, прогностичної й діагностичної значимості таких показників у процесі корекції функціонально-резервних можливостей серцево-судинної системи підлітків недостатньо.

Мета: визначити рівні функціонального резерву серця за даними індексу Руф'є та вивчити фізичну працездатність школярів 12-14 років різних медичних груп.

Матеріали та методи. Обстежено 178 школярів сьомих-восьмих класів віком 12-14 років (85 хлопців та 93 дівчини). Усі учні добровільно взяли участь у цьому експерименті, а також було отримано письмову згоду їх батьків. Фізична працездатність досліджувалась за показниками велоергометричної проби PWC170. Розподіл учнів на медичні групи проводили за показниками рівня функціонально-резервних можливостей серцево-судинної системи, що проводять за індексом Руф'є. Статистичний аналіз результатів здійснювався за допомогою пакету прикладних програм Statistica-V.10.0. Нормальність розподілу перевіряли за критерієм Колмогорова-Смірнова. Досліджувані показники описані медіаною (Ме) і 25, 75 перцентилями. Взаємозв'язки досліджуваних показників аналізували за коефіцієнтами рангової кореляції Спірмена. Для визначення достовірності відмінностей показників застосовували критерій Краскела Уоліса.

Результати. До основної групи увійшло 13,5 \% підлітків, до підготовчої групи - 35,4 \%, до спеціальної медичної групи - 51,1 \% школярів. Серед учнів-спортсменів 25,9 \% хлопців й 45,4 \% дівчат відносяться до спеціальної медичної групи. У школярів-спортсменів кореляційні взаємозв'язки показників індексу Руф'є й тесту PWC 170 низькі й статистично незначимі. Показники фізичної працездатності в межах 25-75 перцентилів практично не відрізняються у різних медичних групах. Це свідчить про те, що у спеціальній медичній групі $є$ школярі з середнім і високим рівнем фізичної працездатності.

Висновки. Встановлені вікові й статеві відмінності функціонального резерву серця школярів визначають необхідність розробки диференційованих підходів до оцінки індексу Руф'є. Фізична працездатність в різних медичних групах варіює у досить широких діапазонах. Розподіл учнів на медичні групи за показниками індексу Руф'є не відображає рівня фізичної працездатності школярів та, відповідно, їх реальних адаптивних можливостей. Необхідні подальші вивчення інформативності застосування проби Руф’є для розподілу школярів на медичні групи.
\end{abstract}

Ключові слова: підлітки, проба Руф’є, фізична працездатність, медичні групи.

\section{ВЗАИМОСВЯЗЬ ФУНКЦИОНАЛЬНОГО РЕЗЕРВА СЕРДЦА И ФИЗИЧЕСКОЙ РАБОТОСПОСОБНОСТИ ПОДРОСТКОВ СПЕЦИАЛЬНОЙ МЕДИЦИНСКОЙ ГРУППЫ}

\author{
Ситовский А.М., Андрейчук Я., Усова А.В., Якобсон А.А., Ульяницкая Н.Я., Цюпак Т.Е. \\ Вольнский нацииональныцй университет имени Леси Украинки, Луцฺк, Украина \\ andriy.sitovskiy@gmail.com;
}

Актуальность. Наиболее распространенными индикаторами оценки эффективности здоровьесберегающих технологий являются показатели деятельности сердечно-сосудистой системы подростков. Сегодня сведений количественного обоснования информативности, прогностической и диагностической значимости таких показателей в процессе коррекции функционально-резервных возможностей сердечно-сосудистой системы подростков недостаточно.

Цель: определить уровни функционального резерва сердца по данным индекса Руфье и изучить физическую работоспособность школьников 12-14 лет различных медицинских групп.

Материалы и методы. Обследовано 178 школьников седьмых-восьмых классов в возрасте 12-14 лет (85 мальчиков и 93 девочки). Все ученики добровольно приняли участие в этом эксперименте, а также было получено письменное согласие их родителей. Физическая работоспособность исследовалась по показателям велоэргометрической пробы PWC170. Распределение учащихся на медицинские группы проводили по показателям уровня функционально-резервных возможностей сердечно-сосудистой системы, проводимых по индексу Руфье. Статистический анализ результатов осуществлялся с помощью пакета прикладных программ Statistica-V.10.0. Нормальность распределения проверяли по критерию Колмогорова-Смирнова. Исследуемые показатели описаны медианой (Ме) и 25, 75 перцентилями. Взаимосвязи исследуемых показателей анализировали по коэффициентам ранговой корреляции Спирмена. Для определения достоверности различий показателей применяли критерий Краскела Уоллиса.

Результаты. В основную группу вошло $13,5 \%$ подростков, в подготовительную группу - 35,4\%, в специальную медицинскую группу - 51,1\% школьников. Среди учеников-спортсменов 25,9\% юношей и 45,4\% девушек относятся к специальной медицинской группе. У школьников-спортсменов корреляционные взаимосвязи показателей индекса Руфье и теста PWC 170 низкие и статистически незначимы. Показатели физической работоспособности в пределах 25-75 перцентилей практически не 
отличаются в различных медицинских группах. Это свидетельствует о том, что в специальной медицинской группе есть школьники с средним и высоким уровнем физической работоспособности.

Выводы. Установленные возрастные и половые различия функционального резерва сердца школьников определяют необходимость разработки дифференцированных подходов к оценке индекса Руфье. Физическая работоспособность в различных медицинских группах варьирует в достаточно широких диапазонах. Распределение учащихся на медицинские группы по показателям индекса Руфье не отражает уровня физической работоспособности школьников и, соответственно, их реальных адаптивных возможностей. Необходимы дальнейшие исследования информативности применения пробы Руфье для распределения школьников на медицинские группы.

Ключевые слова: подростки, проба Руфье, физическая работоспособность, медицинские группы. 